
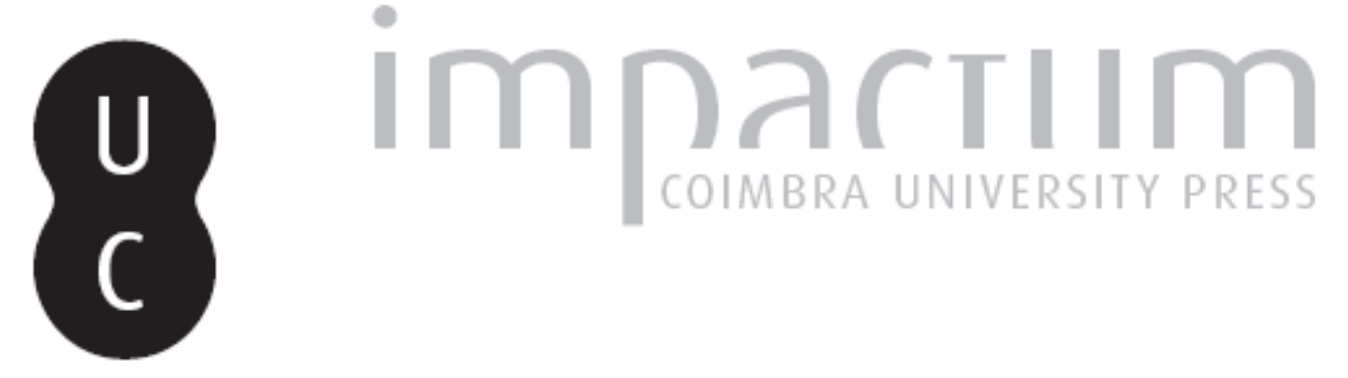

Ética, estética e política: alteridade e subjetivação em Gaibéus, de Alves Redol

Autor(es): $\quad$ Machado, Valéria Aparecida de Souza

Publicado por: Imprensa da Universidade de Coimbra

URL persistente:

URI:http://hdl.handle.net/10316.2/35521

DOI:

DOI:http://dx.doi.org/10.14195/0870-4112_11_22

Accessed : $\quad$ 26-Apr-2023 16:12:35

A navegação consulta e descarregamento dos títulos inseridos nas Bibliotecas Digitais UC Digitalis, UC Pombalina e UC Impactum, pressupõem a aceitação plena e sem reservas dos Termos e Condições de Uso destas Bibliotecas Digitais, disponíveis em https://digitalis.uc.pt/pt-pt/termos.

Conforme exposto nos referidos Termos e Condições de Uso, o descarregamento de títulos de acesso restrito requer uma licença válida de autorização devendo o utilizador aceder ao(s) documento(s) a partir de um endereço de IP da instituição detentora da supramencionada licença.

Ao utilizador é apenas permitido o descarregamento para uso pessoal, pelo que o emprego do(s) título(s) descarregado(s) para outro fim, designadamente comercial, carece de autorização do respetivo autor ou editor da obra.

Na medida em que todas as obras da UC Digitalis se encontram protegidas pelo Código do Direito de Autor e Direitos Conexos e demais legislação aplicável, toda a cópia, parcial ou total, deste documento, nos casos em que é legalmente admitida, deverá conter ou fazer-se acompanhar por este aviso.

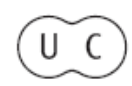




\section{ESTÉTICA E POLÍTICA}

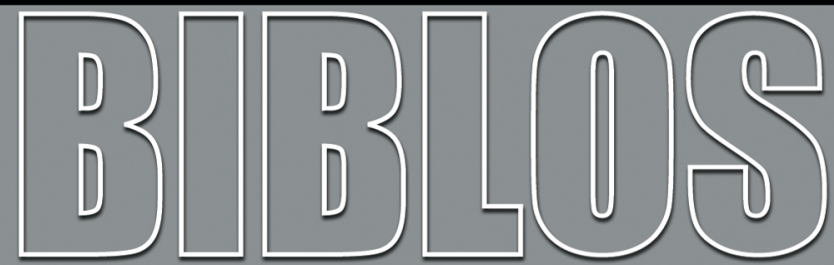

REVISTA DA FACULDADE DE LETRAS UNIVERSIDADE DE COIMBRA 
Biblos, n. s. XI (2013) 511-527

DOI: http://dx.doi.org/10.14195/0870-4112_11_22

Valéria Aparecida de Souza Machado ${ }^{1}$ Bolsista da CAPES (Coordenação de Aperfeiçoamento de Pessoal de Nível Superior). Doutoranda em Literaturas de Língua Portuguesa pela Pontifícia Universidade Católica de Minas Gerais/Brasil.

\title{
ÉTICA, ESTÉTICA E POLÍTICA: ALTERIDADE E SUBJETIVAÇÃO EM GAIBÉUS, DE ALVES REDOL
}

\section{Resumo}

Este trabalho propõe analisar o romance Gaibéus, de Alves Redol, investigando a constituição de subjetividades no e pelo processo enunciativo, à luz de aspectos éticos, políticos e estéticos envolvidos na construção do romance.

Palavras-chaves: Enunciação, Ética. Política, Estética, Subjetividade.

\begin{abstract}
This work contains an analysis of Alves Redol's novel Gaibéus. It investigates the building of sujectivities during and by the enunciatory process by the light of the ethical, political and aesthetic aspects involved in the construction of the novel.
\end{abstract}

Keywords: Enunciation, Ethics, Politics, Aesthetics, Subjectivity.

\footnotetext{
${ }^{1}$ Realizou estágio de Doutoramento Sanduíche na Faculdade de Letras da Universidade de Coimbra/Portugal, no período de 02/11/13 a 02/02/14, sob a orientação do Prof. Dr. Carlos Reis.
} 
O romance Gaibéus, do escritor português Alves Redol, será objeto de análise deste trabalho, sobretudo para investigar a constituição de subjetividades no processo enunciativo à luz de aspectos éticos, políticos e estéticos. Para tanto, alguns conceitos importantes foram levados em conta. Primeiramente, o conceito de "partilha do sensível", cunhado por Jacques Rancière (2009), que fala da necessidade de se partilhar um mundo comum onde todos - nós e nossos semelhantes - têm o direito de se tornarem visíveis, de se fazerem ouvir como falantes, inclusive os que antes não eram percebidos, vistos ou ouvidos. A estética e a política seriam, para Rancière, maneiras de organizar o sensível; de dar a entender, de constituir a visibilidade dos sujeitos e dos acontecimentos. Acrescente-se a isso o fato de que a questão política já carrega implícita a própria questão da ética.

No que tange ao aspecto da subjetivação, além das teorias linguísticas de Bakhtin (1981) e Benveniste $(1989 ;$ 2005) que entendem que a constituição de subjetividades se dá na relação do eu com o outro no uso da linguagem, foram de grande valia as reflexões de Emanuel Levinas (2008) que relaciona a subjetividade à questão da alteridade ao colocar o eu como existência relativa a um outro. Para Levinas a verdadeira alteridade acontece quando o outro se revela a mim; se torna visível a mim e me interpela. Segundo o filósofo, o princípio ético da alteridade reside justamente na responsabilidade do eu diante dessa interpelação do outro.

A partir, pois, desses conceitos brevemente apresentados é que a questão da subjetividade foi pensada na análise do romance.

Gaibéus, escrito em 1939, é tido como marco da literatura neo-realista portuguesa. Grosso modo e de uma maneira geral, o neo-realismo surgiu como corrente artística em meados do século XX, inspirado por tendências marxistas de luta e consciência de classe, voltando-se para os problemas concretos da sociedade, sobretudo para trazer à cena a vida de homens comuns oprimidos e explorados pelas relações sociais e de poder. Em termos estéticos pode-se dizer que o neo-realismo sofreu influências modernistas, principalmente quanto à liberdade linguística em que costumes, anseios e modos de falar da gente do povo foram vistos como material fértil para a produção literária.

Diferentemente do realismo que o precedeu, o neo-realismo não visava apenas a crítica aos costumes e valores burgueses, mas uma tomada consciente de posição em relação às diferenças entre a situação 
privilegiada dos detentores do poder e as necessidades reais do povo. Este começa a aparecer, principalmente nas produções literárias, como parte das preocupações dos intelectuais neo-realistas e não apenas de modo pitoresco como no Romantismo. A arte, para os neo-realistas, foi vista como possibilidade não só de comunicação com o povo, mas de intervenção objetiva na realidade em defesa de interesses de toda uma coletividade oprimida pela mão pesada do poder. A conscientização do povo e a valorização dos seus anseios surgiam como armas poderosas para participação e intervenção na vida social.

Em Portugal o neo-realismo floresceu no contexto histórico-político de uma ditadura repressora que exercia grande censura e policiamento no campo das atividades culturais, principalmente em relação aos que se opunham ao regime. Como sustenta Vítor Viçoso (2011), o neo-realismo surge como "uma cultura de resistência à política ditatorial do Estado Novo", assumindo-se como uma "cultura de contra-poder". Nesse contexto, os escritores empenhados na luta contra o regime ditatorial encontraram condições favoráveis para o desenvolvimento de uma arte que, esteticamente, materializasse seus anseios revolucionários.

O neo-realismo português ou "realismo humanista", como também era denominado, tinha como uma das principais premissas o compromisso do escritor com a realidade, não para reproduzi-la, mas para transformá-la no plano formal, de modo tal que ela pudesse ser interpretada e efetivamente conhecida. Ao escritor neo-realista cabia a responsabilidade de, com sua arte, contribuir para a conscientização do povo e sua consequente emancipação, saindo do lugar de objeto para o de sujeito da História. Nesse sentido, era preciso buscar a forma mais adequada para uma arte que denunciasse o sistema repressor e totalizador e, ao mesmo tempo, se fizesse expressão de um sonho de transformação da realidade social. Isso implicava um novo direcionamento do fazer artístico no sentido de se alcançar a "dialética entre forma e conteúdo", ou seja, a um novo modo de ver e dizer o mundo deveria corresponder uma nova forma, como bem observa Vítor Viçoso. (2011).

Gaibéus se estrutura, pois, alinhado às principais características da estética neo-realista e tem como personagem principal o homem explorado e oprimido como conseqüência de relações sociais injustas. Trata-se do resultado de uma longa reflexão de Alves Redol sobre todo um contexto histórico-cultural vivido pela sociedade portuguesa 
durante o Estado Novo e do papel da literatura enquanto espaço de manifestação de um outro modo de perceber a realidade social, para nela intervir. Na época da publicação do romance era grande a movimentação de intelectuais que, como Alves Redol, participaram na legitimação de uma cultura de 'contra-poder', acreditando que a arte seria capaz de mudar o panorama político e social e levar à derrubada do regime ditatorial.

Desde cedo Alves Redol assumiu uma luta empenhada contra as condições hostis de vida da gente humilde e trabalhadora. Tendo ele próprio experimentado a pobreza e a falta de emprego no tempo em que viveu em África, mostrou-se grande defensor dos menos favorecidos e opositor do regime salazarista. $\mathrm{O}$ escritor, ao ver na literatura uma forma de intervenção e de resistência ao regime, introduziu em sua produção temas, personagens e situações até então ignorados como material de valor para o fazer literário.

Diante da necessidade de entender a real situação dos trabalhadores, escutar sua voz, conhecê-los de perto para, então, falar sobre eles, Alves Redol realizou amplo trabalho etnográfico, instalando-se nos campos de arroz para reunir e coletar dados que subsidiassem a escrita do romance, conforme esclarece já no prefácio do livro:

Numa visita que fiz à Lezíria Grande... descobri a gente da Glória, tão diferenciada no vestuário como nos hábitos de vida e de trabalho dos outros alugados dali. [...] lá me radiquei o tempo disponível para a recolha do materiais etnográficos..." (REDOL, 1965, p.14).

É, portanto, sobre o homem comum, sua situação social e econômica, seu modo de vida e sua cultura que Redol se debruça, para torna-los visíveis como sujeitos partícipes da história, ainda que relegados à margem. Na busca da forma mais adequada a esse novo modo de ver e de dizer a realidade, Redol acomoda o documental a uma escrita poetizada na descrição de ambientes, paisagens e personagens, de onde se entrevê a subjetividade destas e o modo como se relacionam entre si, com o espaço de trabalho e com a natureza que as acolhe e se solidariza com seu sofrimento:

E os ceifeiros passam a outro polígono, espezinhando o restolho, onde na lama ficam marcados os seus pés gigantes. 
Aproveitam esse momento para desentorpecer os braços da fadiga e as pernas do frio. Empinam o tronco, a escorraçar as dores que se acoitaram no dorso, e respiram com sofreguidão o ar da manhã...

Tímido ainda, o Sol escancara luz no arrozal para acariciar os ranchos, emprestando-lhes alento. As mãos entorpecidas pela geada ganham novos vigores e as lâminas das foices parecem mais leves e afiadas.

O marralhar das panículas que tombam alegra de ritmo, talvez porque o calor brando do nascente afague a fronte da malta, como mão invisível que lhe dê carinhos. (REDOL, 1965, p.31).

$\mathrm{Na}$ busca do estabelecimento de um diálogo entre forma e conteúdo Redol concilia a objetividade narrativa e a crueza da realidade cotidiana com os sentimentos, emoções e sensações das personagens. Nesse movimento a voz narrativa se aproxima delas para ouvir o grito mudo que ecoa de suas gargantas secas, pedindo muito mais que água:

As foices voltam a cortar o espaço no derrube dos pés de arroz, logo acamado nas gavelas.

$\mathrm{O}$ ar não se respira - mastiga-se. $\mathrm{O}$ arfar dos peitos torna-se agora mais penoso. As bocas ficam mais sedentas - talvez a sua sede não seja agora só de água. (REDOL, 1965, p.87).

O trabalho etnográfico, quase jornalístico, realizado por Alves Redol para a escrita de Gaibéus rendeu-lhe severas críticas que chegaram a apontar certa primazia do conteúdo sobre a forma, por vezes aproximando o romance da estética realista do século XIX, justamente pelo excesso de descrição e detalhamento. Numa análise mais atenta, porém, pode-se pensar que até mesmo a minúcia e o exagero no detalhe configuram-se em estratégias textuais que vão revelar questões de outra ordem, como se tentou mostrar na análise ora empreendida.

Em Gaibéus Redol já anuncia sua capacidade de manejar a língua, cujo resultado será um estilo peculiar que demonstra, no uso de uma linguagem simples e direta, um novo modo de ver a realidade e ressignificá-la ficcionalmente. A linguagem utilizada expressa o visualismo com o qual o romance foi construído. A descrição minuciosa das paisagens, dos espaços, das personagens, de sua rotina de trabalho, seus gestos e sensações conferem um alto grau de plasticidade ao romance, fazendo dialogar o discurso literário e o pictórico - ou mesmo fotográfico - como se quadros ou fotografias fossem colocados diante do leitor. 
Tal estratégia realça o enfoque marcadamente realista do romance que ao ressaltar a exploração dos trabalhadores nos campos de arroz aponta, metonimicamente, para a exploração do homem pelo homem:

Nos corpos não há tréguas. As pernas estão alquebradas e os braços quase bamboleiam sem ganas. Os troncos desenham-se a dores e as cabeças pendem como cabeças de enforcados. Nos rostos serzidos de esgares, os olhos apagam-se e as bocas resfolegam a quererem digerir o ar de lava.

E a ceifa não pára - a ceifa não pára nunca. (REDOL, 1965, p. 84).

Ainda em relação ao aspecto visual/fotográfico do romance é preciso pensar que seu contexto de produção coincidiu com um período fortemente marcado pela censura. Nesse sentido, a realidade crua que o romance se propôs a denunciar talvez só pudesse ser mostrada como flashes, como quadros. Daí sua estruturação em capítulos estanques, sem encadeamento lógico entre si, com fortes marcas de descrição, aproximando-se, por isso mesmo, da fotografia.

A narrativa se divide em capítulos que se apresentam autônomos e que não mantêm uma relação de continuidade entre si, num movimento que faz com que a história não se alinhave capítulo a capítulo. A cada capítulo uma narrativa miúda é acrescentada, como se o olhar do narrador focalizasse uma personagem em particular para mostrar, também, um pouco da sua história. O rompimento com a linearidade narrativa parece querer contar não apenas uma história, mas várias ao mesmo tempo: histórias de homens comuns que sofrem, mas também sonham e desejam. Tal movimento dá visibilidade a esses indivíduos e suas histórias, o que de certa forma rasura a estrutura hegemônica do sistema sobre o qual o romance fala.

O narrador de "Gaibéus" é peça importante na montagem do romance. Dotado de elevado grau de onisciência, ele tudo vê e observa; parece ouvir até mesmo os pensamentos mais íntimos das personagens. Como se levasse consigo uma máquina fotográfica focaliza cada detalhe, cada pormenor para então descrevê-lo, de modo que nem mesmo o mínimo movimento passe despercebido como, por exemplo, na descrição da chegada dos gaibéus à Lezíria Grande:

Logo apareceram os primeiros ceifeiros, a passo estugado. O grupo cindiu-se. Uns continuaram a marcha, carril adiante, afeitos ao ambiente daquela 
emposta, em granjeios e segas; outros ficaram-se a mover a cabeça e a olhar à volta, estranhos à imensidão da Lezíria, que se desdobra até ao infinito, numa chã retalhada por pastagens, poisios e searas. (REDOL, 1965, p. 22).

Esse olhar atento capta flashes de uma realidade cruel e mostra, ao leitor, cenas das condições precárias às quais os trabalhadores eram submetidos: amontoados como animais, os ceifeiros dormiam num aposento comum onde mal conseguiam descansar o corpo após longo dia de árduo trabalho: "Homens e mulheres, enrolados nas mantas listradas, dormem pelo chão, em ressonares profundos, sobre esteiras ou em palha, como o gado que está na mota a remoer." (REDOL, 1965, p.26).

Interessante é pensar no conceito de realidade que envolve o romance e seu contexto de produção: aí, a realidade já não é vista como algo dado, mas determinada pelas relações sócio-culturais. Nesse sentido, a proposta textual coaduna com a plataforma do movimento neo-realista em sua pretensão de intervir na realidade social, em defesa daqueles indivíduos prejudicados por relações sociais desiguais e injustas. A ocupação dos espaços, por exemplo, é reveladora do abismo que separa trabalhadores e proprietário de terra e evidencia os lugares sociais que ocupam. Enquanto os ceifeiros habitavam "as poisadas requentadas que nem fornos", divididas com aranhas e carunchos, o "aposento maior" era destinado aos capatazes e a casa do rancho, confortável e arejada, abrigava o patrão.

Nota-se, ainda, que a ocupação dos espaços obedece a uma hierarquia das posições de cada um na escala social. Tal estrutura hierárquica também é entrevista na postura diferenciada assumida pelas personagens. O patrão sempre se dirigia aos trabalhadores em cima de seu cavalo, o que demonstra a posição de superioridade ocupada por ele. Os trabalhadores, por seu turno, à aproximação do patrão, mantinham suas cabeças pendidas para baixo em sinal de respeito, só podendo dirigir o olhar a ele quando ordenados: “_Pois seu Francisco, é preciso ensinar a gente do seu rancho a olhar-me de frente quando eu lhe falo..." (REDOL, 1965, p. 96).

Os capatazes, a despeito de serem também empregados, reproduziam a estrutura hierárquica de poder. Isso se observa, por exemplo, quando conduziam os ceifeiros ao local de trabalho: "Os capatazes vêm à frente, de marmeleiros na mão, como guias do rebanho que levanta uma gaze de poeira no caminho..." (REDOL, 1965, p. 29); ou quando 
apoiavam as atitudes injustas do patrão ao oferecer aos trabalhadores um pagamento abaixo do devido para a debulha do milho. Mesmo sabendo se tratar de atitudes injustas, agindo assim os capatazes reproduziam a estrutura de poder, mantendo a ideia de que o lucro só se alcançava pela prática da mais valia: "O outro pensava que não era coisa de muita justiça, mas o patrão dava-lhe tal confiança, como se falasse a um sócio, que ele devia puxar a sardinha àquela brasa." (Redol, 1965, p. 108).

Por vezes a narrativa se utiliza de estratégias que mostram o movimento da perda gradativa da humanidade das personagens, até seu rebaixamento à condição de animais ou máquinas. Isso parece representar o próprio modo como age o sistema capitalista em seu movimento de reificação do homem, onde a perda de identidade é quase que inevitável. Um exemplo é a não nomeação da grande maioria das personagens, o que indicia sua condição de anonimato, de seres colocados à margem. Servindo apenas como peças que movimentam um sistema maior e mais poderoso, eles eram apenas gaibéus, anônimos, ninguém: "Mas eles eram gaibéus e aos gaibéus ninguém fiava. O que é um gaibéu? Quem sabe donde vem e para onde vai um gaibéu?" (REDOL, 1965, p. 93). A identidade das personagens, seu rosto restavam invisíveis e o que importava eram apenas a força do corpo e a disposição para o trabalho:

Têm ganas de se deixar cair, enrodilhados na resteva húmida dos canteiros, buscando com a boca sedenta o refofo da água que ressuma à pressão dos seus pés... A ceifa, porém, vai sempre adiante - sempre adiante que lá em baixo, no aposento, o patrão está a fazer contas à colheita, que correu de boa maré... Por isso o cansaço dos ceifeiros tem de ser desfeito pelos brados dos capatazes...

- Eh, tu!... Anda-me lá mais ligeiro, que da tua banda fica uma ponta. (REDOL, 1965, p. 35).

Interessante é que mesmo personagens nomeadas perdem sua identidade depois que chegam à Lezíria Grande, como é o caso de Rosa e Tí Maria do Rosário. A primeira é escolhida pelo patrão e obrigada a se deitar com ele, mesmo contra sua vontade. Sentindo-se 'manchada' pela perda da virgindade, a personagem se vê destituída de sua identidade primeira e imagina que ao voltar para casa outra identidade the será atribuída, quando passará a ser chamada de' Rosa da Rua Pedro 
Dias', rua dos bordeis onde vivam as prostitutas. Tí Maria do Rosário, já doente e alquebrada pela febre das sezões, sonha ter se transformado em um feixe de arroz sendo debulhado pela máquina. Ainda que essa mutação tenha se dado num momento de delírio causado pela febre, a cena revela não só a perda de identidade, mas de sua condição humana ao se transformar em 'coisa'.

Por outro lado, personagens antes anônimas ganham uma identidade a partir do momento em que a narrativa realça sua humanidade. É o caso dos três rapazes gaibéus, antes chamados apenas de "agueiros", que depois de se tornarem amigos dos rabezanos são por estes nomeados - ainda que com apelidos - e recebidos como novos membros do grupo:

O Fomecas propôs aos outros que os três gaibéus fizessem parte do grupo... O Cadete pôs-lhe a mão no ombro e acenou com a cabeça ao Fomecas. O Passarinho achou bem... E naquela noite ficaram com o nome... Os três gaibéus perdiam naqule momento todo o passado. Não pertenciam agora ao rancho do Francisco Descalço... Já eram outros... (REDol, 1965, p. 73).

Além de anônimas as personagens, em sua maioria, também são destituídas de voz. A narrativa mostra que diante do sistema - representado pelo patrão e pelos capatazes - os trabalhadores não têm direito de se manifestarem, devendo apenas a obediência: "Peitos a estalar como gleba estorricada de securas - peitos aberto de dores fundas. Só as tosses ali falam. As tosses e os capatazes - e o patrão." (REDOL, 1965, p. 92) (grifos meus). Impossibilitados de falar, de se fazerem sujeitos pelo uso da palavra, o olhar muitas vezes cumpre a função da voz para externar sentimentos, angústias, sofrimento, solidariedade:

Os homens enfiam os barretes ou os chapéus que deixaram pendurados nos cabides dos alforjes; as mulheres ajeitam os lenços e os cabelos desataviados, sem ganas de voltar para a ceifa. Olham-se estranhos, sem palavras, movendo-se em gestos lentos. (REDOL, 1965, p. 26).

A outra ofereceu-lhe o ombro para que aquela companheira não fique para trás. Vão mais leves as duas com os pesares repartidos. Olham-se às vezes e não sabem falar. (REDOL, 1965, p. 166). 
A voz narrativa também tem a função de fazer ouvir os destituídos de voz. O narrador fala por eles, mostra o que eles não podem dizer. Não por acaso a certa onisciência de que o narrador é dotado, pois que conhece cada personagem, cada pensamento seu, cada gesto e sentimento: "Nunca viram barcos de mar, mas constroem-nos na imaginação e adivinham-nos a romper ondas e temporais, sempre envolvidos de luz..." (Redol, 1965, p. 142). Essa pluralidade de vozes que se ouve através da voz narrativa converge para o corpo coletivo que o romance quer mostrar, corpo este formado por homens e mulheres que contam, através dos gestos, olhares, sensações e emoções suas histórias de sofrimento, alegria e amargura.

Por vezes a voz autoral se faz ouvir na narrativa como se estivesse a alertar, a aconselhar as personagens (e os leitores) mostrando, pela metáfora dos estorninhos a importância da união e da luta coletiva para a saída do anonimato e da condição de subalternidade. Tal estratégia vai ao encontro da proposta neo-realista de arte engajada em que o intelectual aparece como guia do povo, como pedagogo das massas:

A nuvem de estorninhos não cessa de se enovelar e subir, de despenhar-se e fugir. Os estorninhos juntam-se para se defenderem do milhanos que os espreita; já sabem que se dispersarem as garras não os poupam. Assim, em multidão, o perigo afasta-se. Os estorninhos ensinam os homens - os homens teimam ainda em não compreender a lição. (REDOL, 1965, p. 130-131).

Importante, nesse sentido, é a presença da personagem denominada "ceifeiro rebelde". A narrativa confere um espaço textual privilegiado a essa personagem que, de certa forma, representa um herói coletivo, na medida em que sua figura metonimiza a consciência de classe almejada pelo autor com a escrita do romance:

Para o ceifeiro rebelde os brados dos aguadeiros assemelham-se a gritos de socorro no meio do incêndio. Sente-se mais abatido do que os outros, porque compreende as causas da angústia do rancho e sabe que os outros sofrem mais. Ele tem um norte. $\mathrm{E}$ os camaradas ainda não encontraram bússola.

'Se todos a tivessem...”' (Redol, 1965, p. 83). 
Observa-se, ainda, que essa personagem se configura tal como o romance, num movimento de resistência ao regime e seu sistema opressor. Não por acaso o nome que recebe - ceifeiro rebelde - ainda que não seja verdadeiramente um nome. Não por acaso, também, o fato de a tomada de consciência da personagem se dar de forma velada, o que talvez se justifique pela impossibilidade de dizer/criticar abertamente o regime em razão da censura. Por vezes, parece que a voz dessa personagem - expressa somente através de seus pensamentos, apresentados no texto pela voz narrativa - se faz eco da própria voz autoral que está ali a conduzir o povo a uma tomada de consciência; a sinalizar que a luta não é de um homem só, mas de toda uma coletividade: "O ceifeiro rebelde pensava que estavam a tirar o pão a eles próprios; se todos percebessem, nunca ninguém pegaria numa maçaroca. E o trabalho seria pago ao dia, porque a ceifar ou na descamisa as barrigas não achavam diferença." (REDOL, 1965, p. 110). Talvez por isso mesmo, por estar sozinho na luta, é que o ceifeiro rebelde, apesar de ter consciência, não consegue sair nem tirar os outros da condição de oprimidos e marginalizados.

A música também aparece como uma forma de resistência ao anonimato e à perda de identidade. Durante o trabalho de colheita os gaibéus não falavam, mas cantavam. Cada música entoada, além de representar um cadinho da cultura popular e da tradição daquele povo, coincidia com um momento vivido pelas personagens, cujos sentimentos - de tristeza, descontentamento com as atitudes dos capazes, alegria, saudade, cansaço - eram expressos nas letras das cantigas. O exemplo a seguir mostra uma cantiga entoada no momento em que os trabalhadores, mortos de sede e de cansaço, são vigiados pelos capatazes de modo a não pararem o serviço para tomar água: "Vento fresco é maré boa, vento fresco é maré boa. Mas nem sempre pode ser... Seu João já vai arriba... Seu João já vai arriba e eu aqui a padecer." (REDOL, 1965, p. 38/39). Além disso, a música parecer ter, ainda, um sentido alentador na medida em que as cantigas remetem as personagens a tempos e espaços outros, distantes dali, trazendo um alívio, ainda que momentâneo, às dores do presente.

Digno de registro é o modo como a narrativa representa a exploração dos trabalhadores e a opressão do sistema através do movimento que vai desinvestindo o homem de sua humanidade para transformá-lo em máquina, num nítido processo de 'coisificação'. De homens, passam a objetos com uma função específica - a de produzir -, além de serem vistos como posse do dono das terras: 
O Agostinho Serra era o dono do arrozal e dos ceifeiros. Eles não passavam de alugados - serão homens? ... As máquinas não pensam - e eles poderão pensar? Todos se sentem ligados a um gerador comum que lhes imprime movimento acelarado... (REDOL, 1965, p. 91).

O jogo perverso do sistema capitalista age de modo a garantir a mais valia: "Os patrões querem pessoal que não tenha domingos e se alimente de jornas baixas. Por isso as mondas são feitas por gaibéus e Carmelo." (REDOL, 1965, p. 65). Numa crítica velada ao progresso com seu lema "adiante sempre", produzir mais para lucrar mais, a narrativa por vezes se faz num ritmo acelerado, quase sem fôlego, materializando, na própria escrita, o movimento apressado e repetitivo da produção:

Mais, sempre mais - agora ainda mais... O patrão da companhia do arrozeiro está ali a dois passos...Foices ligeiras e eles não sentem as mãos. Caras à seara, caras à resteva. Ramalhar de espigar e estalidos nas gavelas. As cabeças num rodopio, dos xabocos ao céu cinzento - tudo em vertigem... Mais depressa ainda...Mãos ligeiras - mas eles não sentem as mãos... é preciso mais pressa, cada vez mais pressa - sempre mais. (REDOL, 1965, p. 92-93).

Na impossibilidade de reagir, os trabalhadores se alienam e aceitam a condição de estarem ali apenas como pequenas peças de uma engrenagem maior: "_Eh, tu! Anda-me lá mais ligeiro, que da tua banda fica uma ponta. O outro volve-lhe o olhar humilde de animal pacífico." (REDOL, 1965, p. 35) (grifos meus). A despeito de todo o sofrimento, a oportunidade de trabalho é a garantia do alimento certo porque, para eles, "a ceifa é o pão".

É também no corpo que a opressão se materializa. Na chegada à lezíria os trabalhadores "vinham a passo estugado", com seus corpos dispostos para o trabalho, na esperança de suprirem a escassez dos últimos anos. Aos poucos, o corpo, já doente e cansado, se faz em pedaços, fragmenta-se, metaforizando o processo de desumanização, de despedaçamento de sua própria identidade, na medida em que vão se transformando em objetos ou mesmo no próprio trabalho; nas peças das máquinas que debulham os feixes de arroz, como nesta passagem: "Parece que dos braços as carnes caíram e só ficaram os ossos, como tomados de reumático, e os tendões retesados, como correias de debulhadoras em 
movimentos" (REDOL, 1965, p. 37); e nesta outra: “As mãos não conseguem ficar agarradas aos pulsos. Apodreceram, talvez. Eles não as sentem, mas as foices continuam a cortar espigas...” (REDOL, 1965, p. 91).

É interessante notar que, se por um lado, o romance de Redol se quer perto da realidade social concreta, do homem concreto, mantendo certa objetividade na descrição das cenas justamente para ser fiel ao compromisso de testemunhar "um dos mais profundos aspectos da realidade da vida portuguesa", por outro, a narrativa opera no sentido de se contrapor ao movimento linear e contínuo do progresso, constituindo-se como resistência e rasurando o sistema capitalista. Em vários momentos os tempos são embaralhados misturando passado e presente, principalmente quando a narrativa utiliza os recursos da rememoração e do monólogo interior. Tal estratégia parece ser uma tentativa de desacelerar o processo que o próprio romance descreve, para colocar em evidência o homem e não a máquina.

Também se configura uma forma de resistência à reificação o movimento do romance no sentido de realçar a subjetividade de algumas personagens, principalmente quando toca em suas questões individuais, eivadas de sonho e desejo, através das pequenas histórias introduzidas no meio dos capítulos. No capítulo "Sete estrelas no céu", apesar do título bem ao gosto romântico, realça-se a relação de amizade estabelecida entre os rapazes gaibéus e os rabezanos, quebrando a rivalidade que se mantinha entre os dois grupos. Ao serem nomeados pelos rabezanos, como já mostrado, os gaibéus ganham uma identidade. Durante as brincadeiras e a contação de histórias dos rapazes na areia da praia o lúdico, a imaginação e a fantasia eram ativados permitindo às personagens sonharem com outros mundos, desejarem uma vida diferente daquela. Na imagem dos gaibéus em sua vontade de se lançar ao futuro e buscar caminhos diferentes, a narrativa mostra o próprio ser humano movido pelo desejo: "Não havia a seus olhos só planície e céu - havia o futuro a rasgar-se para além daquele céu e daquela planície. Outras gentes, outras casas, outras estradas... uma vida nova que os faria homens." (REDOL, 1965, p. 168).

Em outro capítulo, "Trégua", a rememoração de uma história de amor se contrapõe à crueza da realidade que a narrativa descreve. Ao tomar o filho sujo e doentinho nos braços durante uma pequena trégua na colheita, uma mulher relembra/revive um amor do passado. Todo o capítulo transita entre sonho e realidade, embaralhando tempos e 
espaços. Apesar de a história lembrada ser, também, uma história de abandono, já que depois de seduzi-la o homem a deixa, o que a narrativa salienta é a perspectiva daquela mulher enquanto ser desejante. $\mathrm{Na}$ imagem do filho que tem nos braços, fruto do amor vivido/proibido, ela rememora o passado e, por instantes, revive uma vida inteira movida pelo amor e pelo desejo:

Pendeu a cabeça no peito, revendo-se no filho, débil no seu corpo franzino. Via-o agora crescer-lhe nos braços, usar cinta vermelha e barrete verde, ter no rosto um sorriso gaiato, e estar ali ao afago das suas mãos, dizendo-lhe as mesmas palavras daquele eguariço que a possuíra... Entendia agora aquela cantiga que não sabia se vinha de alguma voz, se das suas recordações. Era uma canção do passado - do passado que tinha entre os braços, a dormitar. (REDOL, 1965, p. 51).

O embaralhamento dos tempos e o privilégio que o narrador dá ao monólogo, ao tempo interior das personagens, a seus sonhos e fantasias, faz com que elas passem a ser o ponto de referência a partir do qual outros tempos e espaços são construídos.

Ponto relevante na estética neo-realista de Alves Redol é o tratamento dado à linguagem oral/popular, pela linguagem literária. O romance se constrói num movimento que explora os aspectos da oralidade do povo ribatejano, valendo-se de palavras e expressões que the são próprios. Tal movimento constitui um modo peculiar de aproximação e escuta das personagens, em que a própria escrita tenta dar conta do modo de falar e se de expressar da gente da lezíria:

Eh, gente! Vá d’arribar, qu'o dia não tarda.” (REDOL, 1965, p. 26, grifos meus).

- Deixa lá, mulher, não t’amofines. Ora tu!... Deixa, que ele 'tá doudo... (REDOL, 1965, p. 33, grifos meus).

- S'o patrão não andasse de fogo no rabo por mor do rancho, seis dias de molho davam-lhe uns séquitos bem bons. Assim... ainda adrega uma seara como por aqui não há outra. (REDOL, 1965, p. 21).

A valorização da linguagem oral parece representar, ainda, uma maneira de revitalizar a cultura popular para que esta fosse reconhecida 
como parte da cultura nacional. Nesse sentido, tal estratégia aponta para dois aspectos importantes do neo-realismo de Alves Redol: o político que não deixa de contemplar o ético - na medida em que traz o povo e sua cultura para a cena social/ficcional e mostra as tensões envolvidas em sua relação com o poder dominante, incluindo-o, também, como sujeito da história e da cultura. $\mathrm{O}$ estético, que busca a adequação de forma e conteúdo, sem perder de vista o compromisso com a representação da realidade. A linguagem popular aparece, então, como elemento de caráter realista dando à narrativa o tom da verossimilhança.

Gaibéus mostra a perspectiva da sociedade capitalista em seu movimento de dessubjetivação dos indivíduos, que são por ela oprimidos e negados. No entanto, em meio à realidade imediata e às questões sociais tratadas pelo romance misturam-se questões humanas que, juntamente com aquelas, são transformadas em material estético. Se as personagens encenadas são anônimas e destituídas de voz, já que impossibilitadas de usar a palavra e se fazerem ouvir no plano social ali encenado, é no plano da enunciação textual - através da sensibilidade do narrador e do tratamento dado à linguagem - que essas personagens são tiradas da posição de objeto, da condição de anonimato, para serem vistas/ouvidas em sua humanidade, constituídas subjetivamente na linguagem textual.

\section{Referências Bibliográficas}

BAKHTin, Mikhail. A interação verbal. In: BAKHTIN, Mikhail. Marxismo e filosofia da linguagem: problemas fundamentais do método sociológico na ciência da linguagem. Trad. Michel Lahud e Yara Frateschi Vieira. 2. ed. São Paulo: Editora Hucitec, 1981, p. 110-127.

BARTHES, Roland. O efeito de real. In: O rumor da língua. Trad. Márcio Laranjeira. São Paulo: Editora Brasiliense, 1988, p. 158-165.

BARTHES, Roland. Efeito de real, ou melhor, de realidade. (LACAN). In: A preparação do romance 1: da vida à obra. Trad. Leyla Perrone-Moisés. São Paulo: Martins Fontes, 2005, p. 143-159.

Benveniste, Émile. A linguagem e a experiência humana. In: Benveniste, Émile. Problemas de linguística geral II. Campinas (SP): Pontes, 1989. 294p. (Linguagem/Crítica) p. 68-80. 
Benveniste, Émile. Da subjetividade na linguagem. In: Benveniste, Émile. Problemas de linguística geral I. Trad. Maria da Glória Novak e Maria Luisa Neri. 5. ed.. Campinas, SP: Pontes Editores, 2005, p. 284-293.

Bотоso, Altamir. A luta entre vítimas e algozes: uma leitura do romance Gaibéus, de Alves Redol. In: Macabéa - Revista Eletrônica do Netlli, volume 1, número 2, dez/2012, p. 210-222, Universidade de Marília/São Paulo. Figueiredo, Vera Lúcia Follain de. Novos realismos, novos ilusionismos. In: Margato, Izabel; Gomes, Renato Cordeiro (ORG.). Novos realismos. Belo Horizonte: Editora UFMG, 2012, p. 119-132.

Montary, Alexandre. Criar a ativar novas realidades. In: MARGATO, Izabel; Gomes, Renato Cordeiro. (ORG.). Novos realismos. Belo Horizonte: Editora UFMG, 2012.

Redol, Alves. Gaibéus. Lisboa: Publicações Europa América, 1965.

Pellegrini, Tânia. Realismo: postura e método. Letras de Hoje, Porto Alegre, v. 42, n. 4, p. 137-155, dez/2007.

Pellegrini, Tânia. Realismo: a persistência de um mundo hostil. In: Revista Brasileira de Literatura Comparada, n. 14, 2009.

Rancière, Jacques. A partilha do sensível: estética e política. Tradução de Mônica Costa Netto. São Paulo: EXO experimental org; Editora 34, 2009 ReIs, Carlos. Textos teóricos do neo-realismo português. Lisboa: Seara Nova Editorial Comunicação, 1981, p. 49-80; p. 129-158.

Rosset, Clément. A ilusão e o duplo. In: O real e seu duplo. Ensaio sobre a ilusão. Trad. José Thomaz Brum. Porto Alegre: L\&PM Editores S/A, 1988, p. 11-19.

RuIz, Castor B. Emmanuel Levinas, alteridade e alteridades - Questões da modernidade e a modernidade em questão. IN: Souza, Ricardo timm de (org. entre outros). Alteridade e ética: obra comemorativa dos 110 anos de nascimento de Emmanuel Levinas. Porto Alegre: EDIPUCRS, 2008.

V Atimo, Gianni. Adeus à verdade. In: Schuller, Fernando; Silva, Juremir Machado da. Metamorfoses da cultura. Porto Alegre: Sumina, 2006, p. 71$-89$.

Viçoso, Vítor. A tragédia do mundo e o neo-realismo. In: A narrativa do movimento neo-realista: as vozes sociais e os universos da ficção. Lisboa: Edições Colibri, 2011, p. 19-58.

VIEIRA, Luandino. A vida verdadeira de Domingos Xavier. Lisboa: Edições $70,1987$. 


\section{Referências eletrônicas consultadas:}

http://www.infopedia.pt/\$neo-realismo

http://auladeliteraturaportuguesa.blogspot.com.br/2008/12/neo-realismo.html http://www.omilitante.pcp.pt/pt/315/Efemeride/646/periodicos.urca.br/ojs/ index.php/MacREN/article/download/332/306

http://lusofonia.com.sapo.pt/Angola.htm

http://www.buala.org/pt/a-ler/o-nacionalismo-militante-em-o-livro-dos-riosde-jose-luandino-vieira 